\title{
Average Body Weight Gain
}

National Cancer Institute

\section{Source}

National Cancer Institute. Average Body Weight Gain. NCI Thesaurus. Code C90363.

The mean value of the amount of weight gained over a period of time. 